\title{
POLA KONSUMSI PANGAN MASYARAKAT SEKITAR KAWASAN HUTAN DI KABUPATEN TAKALAR
}

\author{
(Food Consumption Patterns of Community Around Forest Areas \\ in Takalar Regency) \\ ${ }^{1)}$ Idham Adha, ${ }^{2)}$ Ida Rosada, ${ }^{2)}$ St. Sabahannur \\ ${ }^{1)}$ Mahasiswa Program Studi Magister Agroekoteknologi \\ ${ }^{2)}$ Dosen Fakultas Pertanian Universitas Muslim Indonesia, Makassar. \\ ${ }^{2)}$ Email : ida.rosada@umi.ac.id \\ ${ }^{2)}$ Email : siti_sabahan@yahoo.com
}

\begin{abstract}
The main objective of this study is to examine the demographic, social and economic characteristics of farm households around the forest area, analyze the household food consumption patterns and analyze the relationship between food consumption patterns with the characteristics of farm households in the vicinity of the forest area. This research was conducted in Takalar Regency, namely in Kale Ko'mara Village, Polongbangkeng Utara District, starting in July October 2018. Types of data used are primary data and secondary data with the number of respondents as many as 40 farmers around the forest area. The data that has been collected is analyzed using qualitative analysis and quantitative analysis. The results showed that the demographic, social and economic characteristics of farmers around the area were: 1) the age of the respondents was in the age range of 40-50 years (60.00\%), 2) the highest number of family dependents was 3-4 people (65.00\% ), 3) the dominant education level is elementary school / equivalent $(55.0 \%)$, 4) the type of side jobs are generally planters $(62.50 \%), 5)$ the longest experience of farming in the range of 20-30 years, (60.00\%), 5) the biggest income is Rp. 2,000,000-Rp.3,000,000 / Month (52.50\%), 6) and the highest average expenditure is Rp. 1,500,000 - Rp. 3,000,000 (90.0\%). The food consumption pattern is in accordance with the Hope Food Pattern (PPH) score of 97.8 which means that the distribution and availability of food for households is guaranteed with the composition and availability of adequate food ingredients, influenced by factors of age, income and expenditure characteristics significantly and the educational characteristics factor is very real. The characteristics of the number of family dependents, type of work and experience of farming do not have a significant effect on the patterns of food consumption of farm households around the forest area.
\end{abstract}

Keywords : Forest Area; Consumption Pattern; Food

\section{PENDAHULUAN}

PPH adalah susunan beragam pangan yang didasarkan pada sumbangan energi dari kelompok pangan utama yang bisa diketahui dari pola konsumsi pangan harian dari suatu rumah tangga.Penghitungan PPH diperoleh dari Angka Kecukupan Energi (AKE). Berdasarkan Widyakarya Nasional Pangan dan Gizi (WNPG) tahun 2004
AKE pada tingkat konsumsi adalah 2000 kkal/kapita/hari, sedangkan pada tingkat persediaan adalah $2150 \mathrm{kkal} / \mathrm{kapita} / \mathrm{hari}$. Angka 2000 kkal/kapita/hari ini terdiri dari 1000 kkal kelompok padi-padian, 120 kkal umbi-umbian, 240 kkal pangan hewani, 200 kkal minyak dan lemak, 60 kkal buah/biji berminyak, 100 kkal kacang- kacangan, 100 kkal gula, 120 kkal 
sayur dan buah, serta 60 kkal kelompok pangan lain-lain.

Makanan beragam itu penting untuk kesehatan. Semestinya setiap orang sadar akan makan makanan beragam sehariharinya. Kenyataan tidaklah demikian.Meskipun mengerti, banyak orang yang tidak dapat melakukannya karena keterbatasan daya beli. Tidak semua orang memiliki kemampuan yang sama dalam mengakses pangan secara beragam, sehingga diperlukan upayaupaya untuk mendorong dan memfasilitasi agar setiap orang memperoleh pangan dalam jumlah dan keragaman yang cukup (Forum Kerja Penganekaragaman Pangan, 2003 dalam NurAripin, 2012).

Hasil Penelitian Darwanto (2015) menunjukkan bahwa untuk menjamin keberlanjutan ketahanan pangan melalui peningkatan ketersediaan pangan nasional, utamanya beras sekaligus peningkatan kesejahteraan petani diperlukan kebijakan jangka panjang dan jangka pendek.Untuk jangka pendek masih diperlukan kebijakan perlindungan petani dengan pembatasan impor beras dan didukung dengan kebijakan yang mendorong peningkatan produksi domestik.Untuk jangka panjang kebijakan pembatasan impor tersebut dapat dikurangi secara bertahap namun kebijakan peningkatan produksi domestik masih diperlukan yang disertai pula dengan upaya penganekaragaman konsumsi atau pangan sehingga mengurangi tekanan pada ketersediaan satu macam produk pangan, terutama beras.Konsekuensinya, keanekaragaman ketersediaan bahan pangan perlu ditingkatkan pula dengan didukung agroindustri pengolahan pangan non beras yang berbasis produk dalam negeri agar dapat tersedia dan mudah diperoleh dimana saja.Pengembangan agroindustri tersebut diupayakan agar dapat sekaligus mendorong berkembangnya agroindustri rumah tangga sehingga sekaligus dapat meningkatkan kesejahteraan rumah tangga di perdesaan umumnya dan petani khususnya, menyangkut penelitian ini termasuk petani di sekitar hutan yang daerahnya sering diidentikkan dengan daerah rawan pangan.

Peran hutan sebagai sumber pangan sudah dipahami oleh masyarakat, tetapi jenis pangan dari hutan berbeda berbeda dengan pemahaman pangan dalam konteks yang dimaksud dengan ketahanan pangan saat ini. Pangan terutama berkaitan dengan berbagai komoditi yang dibutuhkan hidup dan peningkatan gizi masyarakat. Jenis pangan dari hutan 
berupa komoditas tanaman buah - buahan sayuran dan obat - obatan. Beberapa jenis tanaman hutan yang menjadi sumber pangan sebagai tegakan hutan diantaranya ada sukun, sagu, aren, serta tanaman bawah berupa umbi - umbian seperti porang, garut, ganyong, dan sebagainya. Jenis jenis pangan ini dihasilkan hutan yang ekosistem hutannya masih utuh.

Suhardi dkk (2002) menyebutkan sasaran program ketahanan pangan melalui pemanfaatan kawasan hutan di Kabupaten Takalar adalah agroforestri yang lebih difokuskan pada agroforestri jenis ketela (agroforestri awal, yakni pada umur satu sampai tiga tahun) sedangkan tegakan yang berumur tiga tahun atau lebih (di bawah naungan).Hal ini dapat dilihat pada areal-areal kehutanan masyarakat dan juga hutan rakyat, salah satunya Hutan Rakyat di Desa Kale Ko'mara Kabupaten Takalar yang dijadikan lokasi penelitian. Hutan rakyat di Desa Kale Ko'mara memadukan tanaman kehutanan dengan tanaman pangan antara lain jagung, ubi kayu, pepaya, pisang, cabai, kacang panjang, dan kacang tanah.

Berkaitan dengan hal tersebut di atas, penulis tertarik untuk meneliti pola konsumsi pangan disekitar kawasan hutan

di Desa Kale Ko'mara Kabupaten Takalar.

\section{Perumusan Masalah}

1. Bagaimana karakteristik demografi, sosial dan ekonomi masyarakat sekitar kawasan hutan?

2. Bagaimana pola konsumsi pangan masyarakat sekitar kawasan hutan?

3. Bangaimana pengaruh karakteristik demografi, sosial dan ekonomi terhadap Pola Pangan Harapan masyarakat disekitar kawasan hutan?

\section{Tujuan Penelitian}

1. Mengkaji karakteristik demografi, sosial dan ekonomi masyarakat sekitar kawasan hutan.

2. Menganalisis pola konsumsi pangan masyarakat sekitar kawasan hutan.

3. Menganalisis pengaruhkarakteristik demografi, sosial dan ekonomi terhadap Pola Pangan Harapan masyarakat disekitar kawasan hutan ?

\section{Manfaat Penelitian}

1. Sebagai bahan informasi tentang pola konsumsi pangan masyarakat sekitar kawasan hutan guna usaha peningkatan ketahanan pangan masyarakat dan perencanaan 
kebijakan hutan kemasyarakatan untuk mendukung program ketahanan pangan kabupaten Takalar Bahan informasi bagi penelitian yang sama pada lokasi berbeda atau penelitian lanjutan pada lokasi yang sama.

2. Sebagai salah satu persyaratan akademik dalam memperoleh derajat magister pada Program Studi Agroteknologi Universitas Muslim Indonesia, serta menambah pengetahuan dan wawasan tentang pola konsumsi pangan sekitar kawasan hutan serta sebagai bahan pustaka bagi penulis.

\section{Kerangka Pikir Penelitian}

\section{KARAKTERISTIK RUMAH TANGGA PETANI HUTAN KEMASYARAKATAN}

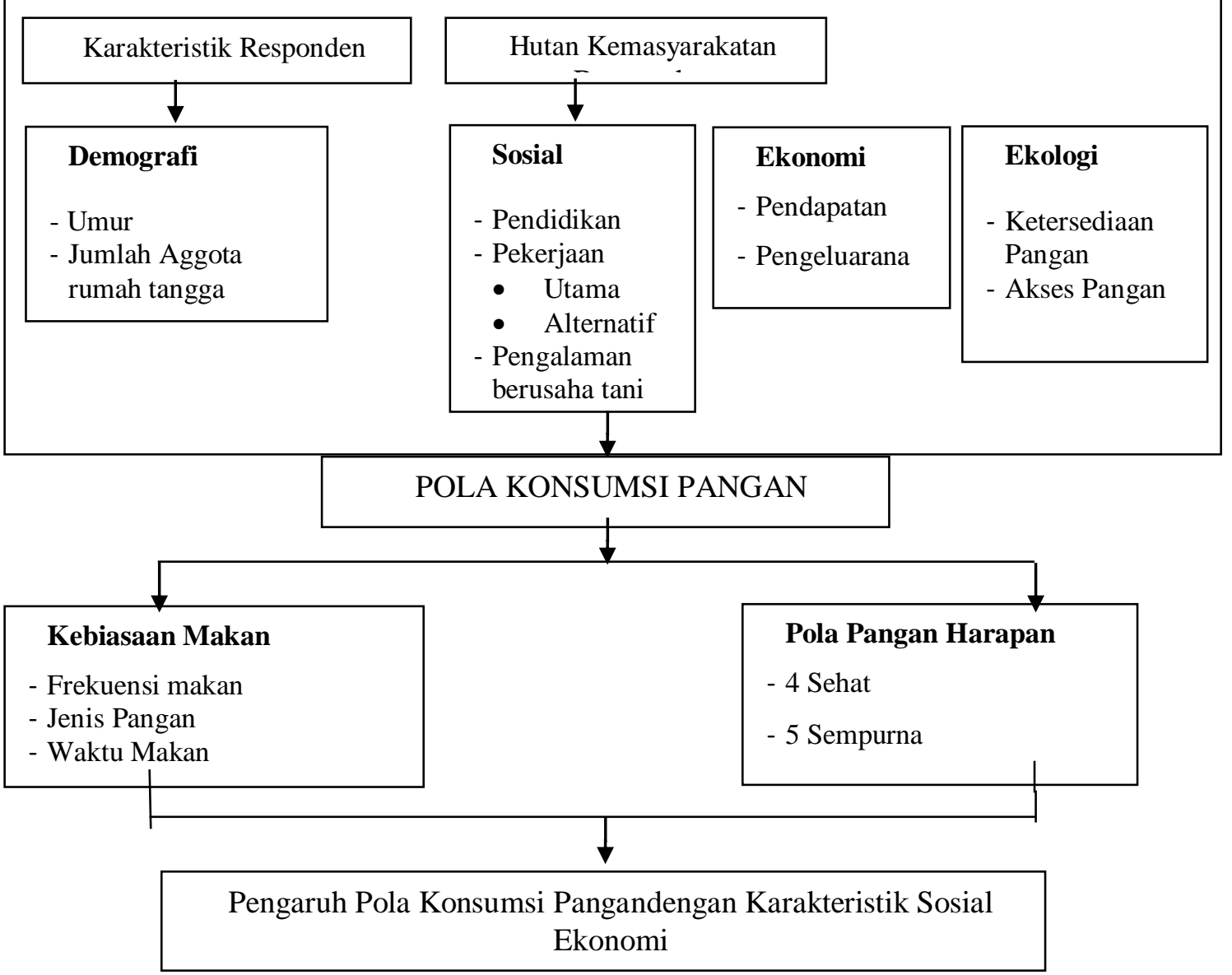

Gambar 1 Kerangka Pikir Pola Konsumsi Pangan Sekitar Kawasan Hutan di Desa Kombara Kab.Takalar. 


\section{Hipotesis}

1. Karakteristik demografi, sosial dan ekonomi masyarakat disekitar kawasan hutan diduga berda pada kisaran umur produktif, jumlah tanggungan besar, pendidikan rendah, jenis pekerjaan umumnya petani, serta besarnya pendapatan dan pengeluaran sesuai dengan kebutuhan.

2. Pola konsumsi pangan masyarakat disekitar kawasan hutandiduga berdasarkan atas kebiasaan makan dan nilai pola pangan harapan.

3. Karakteristik demografi, sosial dan ekonomi diduga berpengaruh signifikan terhadap pola pangan harapan masyarakat sekitar kawasan hutan.

\section{Lokasi dan Waktu Penelitian}

Penelitian ini dilakukan di Kabupaten Takalar, yaitu dengan mengambil sampel di Desa Kale Ko'mara Kecamatan Polongbangkeng Utara, dengan pertimbangan bahwa di 1 (satu) kecamatan tersebut merupakan daerah yang yang memiliki luas kawasan hutan di Kabupaten Takalar.Waktu Penelitian dilaksanakan mulai Julisampai Oktober 2018.

\section{Jenis dan Sumber Data}

1. Data primer, yaitu data yang diperoleh langsung dari responden melalui wawancara dan observasi dengan menggunakan kuisioner (daftar pertanyaan).

2. Data sekunder, yaitu data yang diperoleh dari sumber yang ada kaitannya pada pola konsumsi pangan masyarakat sekitar kawasan hutan, terutama dari lembaga pemerintahan, serta instansi terkait.

\section{Tekinik Pengumpulan Data}

1. Observasi, yaitu pengumpulan melalui pengamatan langsung terhadap kegiatan responden, dengan maksud untuk memperoleh data primer.

2. Wawancara, yaitu pengumpulan data melalui tanya jawab dengan responden yang menggunakan daftar pertanyaan atau kuesioner untuk memperoleh data primer dan data sekunder.

3. Dokumentasi, yaitu pengumpulan data melalui jurnal-jurnal, hasilhasil penelitian terdahulu, dan buku-buku, literatur yang ada kaitannya dengan penelitian guna memperoleh data sekunder. 


\section{Populasi dan Sampel}

Populasi dalam penelitian ini adalah masyarakat petani sekitar kawasan hutan di Kecamatan Polongbangkeng Utara KabupatenTakalar, sedangkn sampel adalah bagian dari populasi yang ditentukan berdasarkan teknik penentuan sampel

Populasi masyarakat petani sekitar kawasan hutan di lokasi penelitian sebanyak 281 Kepala Keluarga yang tersebar pada empat (4) dusun dengan klasifikasi sosial dan ekonomi yang beragam. Besarnya sampel yang diambil, masing-masing $10 \mathrm{KK} /$ dusun yang dipilih secara stratified random dan proporsional, sehingga total sampel secara keseluruhan sebanyak 40 orang atau 40 kepala keluarga.

\section{Metode Analisis Data}

Data yang telah terkumpul di analisis dan disajikan dalam bentukrataan, distribusi frekuensi, tabulasi silang dan persentase.Analisis data dalam penelitian ini menggunakan analisis kualitatif dan analisis kuantitatif.

Untuk mengkaji pengaruh pola konsumsi pangan dengan karakteristik sosial ekonomi masyarakat di sekitar kawasan hutan digunakan analisis regresi linear berganda yang merupakan salah satu teknik statistik untuk menganalisis pengaruh antara dua variabel atau lebih yang bersifat kuantitatif. Analisis regresi berganda dengan persamaan:

$$
Y=b_{0}+b_{1} X_{1}+b_{2} X_{2}+b_{3} X_{3}+b_{4} X_{4}+b_{5} X_{5}+b_{6} X_{6}+b_{7} X_{7}
$$

$\begin{array}{lll}\text { Keterangan : } & & \\ \mathrm{Y} & & \text { Pola Pangan Harapan }(\mathrm{PPH}) \\ \mathrm{b}_{0} & = & \text { Konstanta } \\ \mathrm{X}_{1} & = & \text { Jumur } \\ \mathrm{X}_{2} & = & \text { Pendidikan Anggota Rumah Tangga } \\ \mathrm{X}_{3} & = & \text { Pekerjaan } \\ \mathrm{X}_{4} & = & \text { Pengalaman Berusahatani } \\ \mathrm{X}_{5} & = & \text { Pendapatan Rumah Tangga } \\ \mathrm{X}_{6} & & \text { Pengeluaran Rumah Tangga } \\ \mathrm{X}_{7} & & \end{array}$




\section{Definisi Operasional}

Definisi operasional mencakup beberapa pengertian yang digunakan untuk lebih mengarahkan pelaksanaan penelitian terutama dalam pengambilan data. Adapun definisi operasional yang dimaksud adalah sebagai berikut:

1. Hutan produksi adalah merupakan kawasan hutan yang dimanfaatkan untuk memproduksi hasil hutan. Hasil hutan yang dimaksud bisa berupa kayu atau non kayu.

2. Hutan lindung adalah adalah kawasan hutanyang telah ditetapkan oleh pemerintah atau kelompok masyarakat tertentu untuk dilindungi, agar fungsi-fungsi ekologisnya terutama menyangkut tata air dan kesuburan tanah tetap dapat berjalan dan dinikmati manfaatnya oleh masyarakat di sekitarnya.

3. Populasi adalah semua masyarakat yang berdomisili di wilayah desa penelitian sekitar kawasan hutan.

4. Sampel adalah sebagian dari jumlah dan karakteristik yang dimiliki oleh populasi tersebut.

5. Karakteristik Petani adalah karakter, pembeda atau ciri petani. Karakterkarakter tersebut yang membedakan tipe perilaku petani pada situasi tertentu. Karakteristik dalam penelitian ini meliputi karaktersirtik demografi (umur dan jumlah anggota keluarga), karaktersirstik sosial (pendidikan, pekerjaan dan pengalaman berusahatani) dan karakteristik ekonomi (pendapatan dan pengeluaran rumah tangga).

- Umur adalah usia responden petani sekitar kawasan hutan yang dihitung mulai waktu lahir sampai waktu dilakukan wawancara penelitian ini (tahun)

- Jumlah Tanggungan Keluarga adalah jumlah anggota keluarga petani responden sekitar kawasan hutan yang tinggal bersama dan menjadi tanggungan kepala keluarga.

- Pendidikan formal adalah lamanya petani responnden mengikuti pendidikan formal yang dinyatakan dalam tahun.

- Pekerjaan Pokok adalah pekerjaan yang menyita hampir sebagian besar waktu dan tenaga responden serta memberikan pendapatan pokok bagi masyarakat responden di sekitar kawasan hutan 
- Pekerjaan Sampingan adalah pekerjaan yang dilakukan petani responden dan keluarganya setelah melakukan pekerjaan pokok dan menghasilkan pendapatan tambahan bagi masyarakat

- Pengalaman Berusahatani adalah lamanya petani responden mengelolah usahatani pokok dan usahatani sekitar kawasan hutan yang dinyatakan dalam tahun.

- Pendapatan Rumah Tangga adalah jumlah penerimaan yang berupa uang yang dinyatakan dalam rupiah (Rp) yang merupakan hasil dari berusaha tani termasuk hasil usaha petani dari Hutan Kemasyarakatan yang telah mendapatkan untuk memperoleh hasil hutan non kayu.

- Pengeluaran Rumah Tangga adalah besarnya pengeluaran rumah tangga untuk kebutuhan konsumsi pangan, pendidikan, kesehatan dan lain-lain yang dinyatakan dalam rupiah $(\mathrm{Rp})$

6. Pola konsumsi pangan adalah susunan beragam pangan yang biasa dimasak dan dikonsumsi oleh keluarga seharihari. Disusun berdasarkan frekuensi makan, jenis dan jumlah pangan yang dimakan yang dipengaruhi oleh kebiasaan makan, preferensi dan pantangan.

7. Konsumsi pangan adalah jumlah pangan dan zat gizi yang dikonsumsi oleh rumahtangga yang dihitung dengan mengukur jumlah bahan makanan yang dimasak untuk dikonsumsi beserta kandungan gizinya (energy dan protein).

8. Kebutuhan pangan ideal adalah kebutuhan pangan yang didasarkan pada kecukupan ideal dengan menggunakan pola konsumsi actual.

9. Frekuensi Makan adalah jumlah berapa kali petani responden dan keluarganya mengkonsumsi jenis makan tertentu dalam satu hari

10. Jenis Pangan adalah jenis-jenis pangan yang dikonsumsi petani responden dan keluarganya yang mengandung zat-zat gizi 4 sehat 5 sempurna.

11. Ketersediaan Pangan adalah tersediaannya pangan dalam jumlah yang cukup untuk memenuhi kebutuhan seluruh anggota keluarga.

12. Akses Pangan adalah kemudahan responden dalam memenuhi kebutuhan seluruh anggota keluarga. 
13. 4 sehat adalah makanan sehat yang mengandung 4 nutrisi makanan dalam pemenuhan kebutuhan responden.

14. 5 sehat adalah makanan sehat yang mengandung 4 nutrisi makanan dan disempurnakan dengan susu dalam kelengkapan kebutuhan pangan masyarakat sekitar kawasan hutan.

15. Hutan Konservasi adalah kawasan hutan dengan ciri khas tertentu yang mempunyai fungsi pokok pengawetan keanekaragaman tumbuhan dan satwa serta ekosistennya.

\section{Karakteristik Masyarakat Responden}

Karakteristik Umur Petani Responden sekitar Kawasan Hutan

\begin{tabular}{cccc}
\hline \hline No & $\begin{array}{c}\text { Karakteristik Umur } \\
\text { (Tahun) }\end{array}$ & $\begin{array}{c}\text { Jumlah } \\
\text { (Org) }\end{array}$ & $\begin{array}{c}\text { Persen } \\
(\boldsymbol{\%})\end{array}$ \\
\hline \hline 1 & $<40$ & 5 & 12,50 \\
2 & $40-50$ & 24 & 60,00 \\
3 & $>50$ & 11 & 27,50 \\
\hline \hline & Jumlah & 40 & 100,00 \\
\hline \hline
\end{tabular}

Sumber : Data Primer Setelah diolah, 2018

Karakteristik Jumlah Tanggungan Keluarga Petani Responden sekitar Kawasan Hutan

\begin{tabular}{cccc}
\hline \hline No & $\begin{array}{c}\text { Karakteristik Jumlah } \\
\text { Tanggungan Keluarga } \\
\text { (Orang) }\end{array}$ & $\begin{array}{c}\text { Jumlah } \\
(\text { Org) }\end{array}$ & $\begin{array}{c}\text { Persen } \\
(\boldsymbol{\%})\end{array}$ \\
\hline \hline 1 & $<3$ & 5 & 12,50 \\
2 & $3-4$ & 26 & 65,00 \\
3 & $>4$ & 9 & 22,50 \\
\hline \hline
\end{tabular}

Sumber : Data Primer Setelah diolah, 2018

Karakteristik Pendidikan Petani Responden sekitar Kawasan Hutan

\begin{tabular}{cccc}
\hline \hline No & Karakteristik Pendidikan & $\begin{array}{c}\text { Jumlah } \\
(\text { Org })\end{array}$ & $\begin{array}{c}\text { Persen } \\
(\boldsymbol{\%})\end{array}$ \\
\hline \hline 1 & SD & 22 & 55,00 \\
2 & SMP & 2 & 5,00 \\
3 & SMA & 12 & 30,00 \\
4 & SARJANA & 4 & 10,00 \\
\hline \hline
\end{tabular}

Sumber : Data Primer Setelah diolah, 2018 
Karakteristik Jenis Pekerjaan Sampingan Petani Responden sekitar Kawasan Hutan

\begin{tabular}{|c|c|c|c|}
\hline No & $\begin{array}{c}\text { Krakteristik Jenis Pekerjaan } \\
\text { Sampingan } \\
\end{array}$ & $\begin{array}{c}\text { Jumlah } \\
\text { (Org) }\end{array}$ & $\begin{array}{c}\text { Persen } \\
(\%)\end{array}$ \\
\hline $\bar{~} 1$ & Tidak Ada & 2 & $5,5,00$ \\
\hline 2 & Pekebun & 25 & 62,50 \\
\hline 3 & Peternak & 6 & 15,00 \\
\hline 4 & Pedagang & 4 & 10,00 \\
\hline \multirow[t]{2}{*}{5} & Pengrajin & 3 & 7,50 \\
\hline & Jumlah & 40 & 100,00 \\
\hline
\end{tabular}

Sumber : Data Primer Setelah diolah, 2018

Karakteristik Pengalaman Berusahatani Petani Responden sekitar Kawasan Hutan

\begin{tabular}{cccc}
\hline \hline No & $\begin{array}{c}\text { Karaktersitik } \\
\text { Berusahatani } \\
\text { (Tahun) }\end{array}$ & $\begin{array}{c}\text { Pengalaman } \\
\text { Jumlah } \\
(\text { Org) }\end{array}$ & $\begin{array}{c}\text { Persen } \\
(\boldsymbol{\%})\end{array}$ \\
\hline \hline 1 & $<20$ & 9 & 22,50 \\
2 & $20-30$ & 24 & 60,00 \\
3 & $>30$ & 7 & 17,50 \\
\hline \hline & Jumlah & 40 & 100,00 \\
\hline \hline
\end{tabular}

Sumber : Data Primer Setelah diolah, 2018

Karakteristik Besarnya Pendapatan Masyarakat Responden sekitar Kawasan Hutan

\begin{tabular}{cccc}
\hline \hline No & $\begin{array}{c}\text { Karaktersitik Pendapatan } \\
(\mathbf{R p} / \text { Bulan) }\end{array}$ & $\begin{array}{c}\text { Jumlah } \\
(\text { Org })\end{array}$ & $\begin{array}{c}\text { Persen } \\
(\boldsymbol{\%})\end{array}$ \\
\hline \hline 1 & $<2.000 .000$ & 17 & 42,50 \\
2 & $2.000 .000-3.000 .000$ & 21 & 52,50 \\
3 & $>3.000 .000$ & 2 & 5,00 \\
\hline \hline & Jumlah & 40 & 100,00 \\
\hline \hline
\end{tabular}

Sumber : Data Primer Setelah diolah, 2018

Karakteristik Jumlah Pengeluaran Masyarakat Responden sekitar Kawasan Hutan

\begin{tabular}{cccc}
\hline \hline No & $\begin{array}{c}\text { Karaktersitik Jenis Pengeluaran } \\
(\mathbf{R p} / \text { Bulan })\end{array}$ & $\begin{array}{c}\text { Jumlah } \\
(\text { Org })\end{array}$ & $\begin{array}{c}\text { Persen } \\
(\%)\end{array}$ \\
\hline \hline 1 & $<1.500 .000$ & 2 & 5,00 \\
2 & $1.500 .000-2.500 .000$ & 36 & 90,00 \\
3 & $>2.500 .000$ & 2 & 5,00 \\
\hline \hline & Jumlah & 40 & 100,00 \\
\hline \hline
\end{tabular}

Sumber : Data Primer Setelah diolah, 2018 


\section{Pola Konsumsi Pangan Masyarakat Sekitar Hutan}

Jenis Pangan yang dikonsumsi Petani Responden di sekitar Kawasan Hutan

\begin{tabular}{cll}
\hline \hline No & \multicolumn{1}{c}{ Sumber Pangan } & \multicolumn{1}{c}{ Jenis Pangan } \\
\hline \hline 1 & Sumber Karbohidrat & Beras, Ubi Kayu, Ubi Jalar, Jagung \\
2 & Sumber Protein Nabati & Kacang Tanah, Kacang Kedelai, Kacang Hijau, \\
& & Kacang Merah \\
3 & Sumber Hewani & $\begin{array}{l}\text { Ikan, Daging Ruminansia, Daging Unggas, Telur, } \\
\text { Susu } \\
\text { Minyak kelapa, Minyak sawit, Minyak lain, kelapa, }\end{array}$ \\
& Sumber Lemak & kemiri \\
& Sumber Vitamin dan Mineral & Pisang, Pisang raja, Semangka, Sirsak, Bayam, \\
& & Bayam merah, Daun kelor, Daun singkong, \\
& & Kangkung, Daun Kacang Panjang, Alpukat, Jagung \\
& & Sayur, Wortel \\
\hline \hline
\end{tabular}

Sumber : Data Primer Setelah diolah, 2018

Frekuensi Konsumsi Pangan Petani Responden di sekitar Kawasan Hutan

\begin{tabular}{|c|c|c|c|c|c|c|c|c|}
\hline \multirow{3}{*}{ Jenis Pangan } & \multicolumn{8}{|c|}{ Frekuensi Konsumsi (kali/Hari) } \\
\hline & \multicolumn{2}{|c|}{ <3 Kali } & \multicolumn{2}{|c|}{3 Kali } & \multicolumn{2}{|c|}{4 Kali } & \multicolumn{2}{|c|}{ > 4 Kali } \\
\hline & Jml & $\%$ & Jml & $\%$ & (Jml & $\%$ & 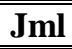 & $\%$ \\
\hline Sayuran & 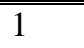 & 2,5 & 30 & 75,0 & 9 & 22,5 & 0 & 0,0 \\
\hline Buah-Buahan & 34 & 85,0 & 5 & 12,5 & 0 & 0,0 & 1 & 2,5 \\
\hline Umbi-Umbian & 31 & 80,0 & 6 & 15,0 & 2 & 5,0 & 1 & 2,5 \\
\hline Pangan Hewani & 24 & 60,0 & 12 & 30,0 & 3 & 7,5 & 1 & 2,5 \\
\hline Kacang-Kacangan & 34 & 85,0 & 6 & 15,0 & 0 & 0,0 & 0 & 0,0 \\
\hline Rata-Rata & 24,8 & 62,5 & 11,8 & 29,5 & 2,8 & 7,0 & 0,6 & 1,5 \\
\hline
\end{tabular}

Sumber : Data Primer Setelah diolah, 2018

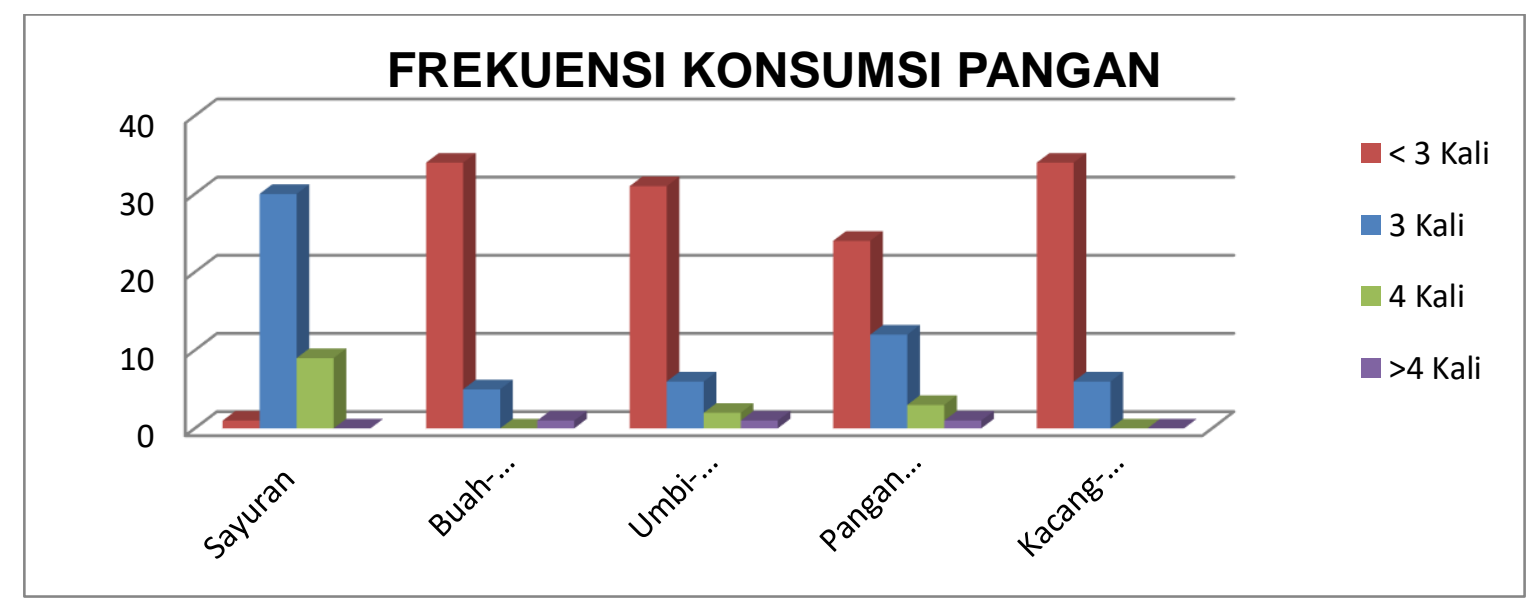

Gambar 2. Diagram Batang Frekuensi Konsumsi Pangan Masyarakat Sekitar Kawasan Hutan di Desa Kale Ko’mara Kecamatan Polombangkeng Utara Kabupaten Takalar 
Idham Adha : Pola Konsumsi Pangan Masyarakat Sekitar Kawasan Hutan di Kabupaten Takalar

Kuantias Pangan Aktual dan Standar Kebutuhan Konsumsi Ideal Masyarakat Sekitar Kawasan Hutan

\begin{tabular}{|c|c|c|c|c|}
\hline \multirow{2}{*}{ No } & \multirow{2}{*}{ Sumber dan Jenis Pangan } & \multicolumn{3}{|c|}{ Kuantitas Pangan } \\
\hline & & (g/kap/hr) & (kg/kap/thn) & (Kkal/kap/hr) \\
\hline (1) & (2) & (3) & (4) & (5) \\
\hline 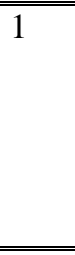 & $\begin{array}{l}\text { Sumber Karbohidrat } \\
\text { - Padi-Padian } \\
\text { a. Beras } \\
\text { b. Jagung } \\
\text { Total } \\
\text { Konsumsi Ideal } \\
\end{array}$ & $\begin{array}{c}247,9 \\
8,6\end{array}$ & $\begin{array}{c}90,5 \\
3,1\end{array}$ & $\begin{array}{c}893 \\
24 \\
\mathbf{9 1 7} \\
\mathbf{1 0 0 0} \\
\end{array}$ \\
\hline & $\begin{array}{l}\text { - Umbia-Umbian } \\
\text { a. Ubi Kayu } \\
\text { b. Ubi Jalar } \\
\text { Total } \\
\text { Konsumsi Ideal } \\
\end{array}$ & $\begin{array}{l}81,8 \\
59,4\end{array}$ & $\begin{array}{l}29,9 \\
21,7\end{array}$ & $\begin{array}{c}90 \\
63 \\
153 \\
\mathbf{1 2 0} \\
\end{array}$ \\
\hline 2 & $\begin{array}{cl}\text { Sumber } & \text { Protein Hewani } \\
\text { a. } & \text { Ikan } \\
\text { b. } & \text { Daging Ruminansia } \\
\text { c. } & \text { Daging Unggas } \\
\text { d. } & \text { Telur } \\
\text { e. } & \text { Susu } \\
\text { Total } & \\
\text { Konsumsi Ideal } \\
\end{array}$ & $\begin{array}{c}310,5 \\
7,3 \\
15,4 \\
65,4 \\
146,2\end{array}$ & $\begin{array}{c}113,3 \\
2,7 \\
5,6 \\
23,9 \\
53,4\end{array}$ & $\begin{array}{c}281 \\
15 \\
27 \\
95 \\
89 \\
\mathbf{5 0 7} \\
\mathbf{2 4 0} \\
\end{array}$ \\
\hline 3 & $\begin{array}{l}\text { Sumber Protein Nabati } \\
\text { a. Kacang Tanah } \\
\text { b. Kacang Kedelai } \\
\text { c. Kacang Hijau } \\
\text { d. Kacang Merah } \\
\text { Total } \\
\text { Konsumsi Ideal } \\
\end{array}$ & $\begin{array}{c}3,5 \\
67,6 \\
12,7 \\
2,2\end{array}$ & $\begin{array}{c}1,3 \\
24,7 \\
4,6 \\
0,8\end{array}$ & $\begin{array}{c}16 \\
193 \\
44 \\
7 \\
\mathbf{2 6 0} \\
\mathbf{1 0 0} \\
\end{array}$ \\
\hline 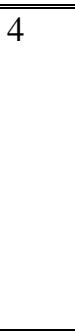 & $\begin{array}{cl}\text { Sumber } & \text { Lemak } \\
\text { a. } & \text { Minyak kelapa } \\
\text { b. } & \text { Minyak sawit } \\
\text { c. } & \text { Minyak lain } \\
\text { d. } & \text { Kelapa } \\
\text { e. } & \text { Kemiri } \\
\text { Total } & \\
\text { Konsumsi Ideal }\end{array}$ & $\begin{array}{c}22,9 \\
19,1 \\
0,0 \\
0,0 \\
0,0\end{array}$ & $\begin{array}{l}8,3 \\
7,0 \\
0,0 \\
0,0 \\
0,0\end{array}$ & $\begin{array}{c}199 \\
172 \\
0 \\
0 \\
0 \\
\mathbf{3 7 1} \\
\mathbf{2 0 0}\end{array}$ \\
\hline 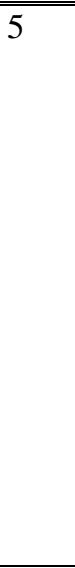 & $\begin{array}{cl}\text { Sumber } & \text { Vitamin \&Mineral } \\
\text { a. } & \text { Pisang } \\
\text { b. } & \text { Semangka } \\
\text { c. } & \text { Sirsak } \\
\text { d. } & \text { Bayam } \\
\text { e. } & \text { Daun kelor } \\
\text { f. } & \text { Daun singkong } \\
\text { g. } & \text { Kacang panjang } \\
\text { h. } & \text { Kangkung } \\
\text { i. } & \text { Alpukat } \\
\text { j. } & \text { Wortel } \\
\text { k. } & \text { Jagung Sayur } \\
\text { Total } & \\
\text { Konsumsi Ideal }\end{array}$ & $\begin{array}{c}32,1 \\
50,7 \\
11,5 \\
19,7 \\
10,3 \\
16,0 \\
10,6 \\
27,2 \\
2,9 \\
4,6 \\
3,2\end{array}$ & $\begin{array}{c}11,7 \\
18,5 \\
4,2 \\
7,2 \\
3,8 \\
5,8 \\
3,9 \\
9,9 \\
1,0 \\
1,7 \\
1,2\end{array}$ & $\begin{array}{c}30 \\
9 \\
7 \\
7 \\
8 \\
15 \\
5 \\
8 \\
0 \\
2 \\
7 \\
\mathbf{9 8} \\
\mathbf{1 2 0}\end{array}$ \\
\hline
\end{tabular}

Sumber : Data Primer Setelah diolah, 2018 
Idham Adha : Pola Konsumsi Pangan Masyarakat Sekitar Kawasan Hutan di Kabupaten Takalar

Pola Pangan Harapan Masyarakat Responden sekitar Kawasan Hutan

\begin{tabular}{|c|c|c|c|c|c|}
\hline Kelompok Pangan & $\begin{array}{l}\text { Konsumsi } \\
\text { Energi (Kkal) }\end{array}$ & \% Total & Bobot & $\begin{array}{l}\text { Skor } \\
\text { PPH }\end{array}$ & Skor Maks \\
\hline Padi-padian & 959,1 & 36,1 & 0,5 & 24,0 & 25,0 \\
\hline Umbi-umbian & 157,0 & 5,9 & 0,5 & 2,5 & 2,5 \\
\hline Pangan Hewani & 507,3 & 19,1 & 2,0 & 24,0 & 24,0 \\
\hline Minyak dan Lemak & 371,2 & 14,0 & 0,5 & 5,0 & 5,0 \\
\hline Buah/Biji Berminyak & 0,0 & 0,0 & 0,5 & 0,0 & 1,0 \\
\hline Kacang-kacangan & 259,8 & 9,8 & 2,0 & 10,0 & 10,0 \\
\hline Gula & 91,0 & 3,4 & 0,5 & 2,3 & 2,5 \\
\hline Sayur dan Buah & 138,4 & 5,2 & 5,0 & 30,0 & 30,0 \\
\hline Lain-lain & 171,3 & 6,5 & 0,0 & 0,0 & 0,0 \\
\hline Jumlah & 2655,1 & 100,0 & 11,0 & 97,8 & 100,0 \\
\hline
\end{tabular}

Sumber : Data Primer Setelah diolah, 2018

Pengaruh antara Pola Konsumsi Pangan dengan Karakteristik Masyarakat Sekitar Kawasan Hutan

Koofisien Regeresi Pengaruh Karakteristik terhadap Pola Pangan Harapan Masyarakat Sekitar Kawasan Hutan

\begin{tabular}{|c|c|c|c|c|c|c|}
\hline & \multirow[t]{2}{*}{ Model } & \multicolumn{2}{|c|}{$\begin{array}{c}\text { Unstandardized } \\
\text { Coefficients }\end{array}$} & \multirow{2}{*}{$\begin{array}{c}\text { Standardized } \\
\text { Coefficients }\end{array}$} & \multirow[t]{2}{*}{$\mathbf{t}$} & \multirow[t]{2}{*}{ Sig. } \\
\hline & & B & Std. Error & & & \\
\hline \multirow[t]{8}{*}{1} & (Constant) & 93.54 & 14.95 & 0.00 & 6.26 & 63.09 \\
\hline & $\mathrm{X} 1$ & -3.02 & 0.35 & 0.40 & -0.86 & -0.02 \\
\hline & $\mathrm{X} 2$ & -7.00 & 1.49 & 0.64 & -0.47 & -0.13 \\
\hline & $\mathrm{X} 3$ & 7.40 & 0.50 & 0.15 & 1.48 & 1.76 \\
\hline & $\mathrm{X} 4$ & 1.44 & 0.40 & 0.67 & 2.43 & 0.65 \\
\hline & $\mathrm{X} 5$ & 9.78 & 1.88 & 0.61 & 0.72 & 0.81 \\
\hline & X6 & 3.38 & 0.92 & 0.40 & 1.86 & 0.05 \\
\hline & $\mathrm{X} 7$ & 3.17 & 0.04 & 0.45 & 1.77 & 0.12 \\
\hline
\end{tabular}

Sumber : Data Primer Setelah diolah, 2018 
Analisis Varian Pengaruh Karakteristik terhadap Pola Pangan Harapan Masyarakat Sekitar Kawasan Hutan

\begin{tabular}{|c|c|c|c|c|c|c|}
\hline \multirow{3}{*}{ Multiple R } & \multirow{3}{*}{ R Square } & \multirow{3}{*}{$\begin{array}{l}\text { Adjusted R } \\
\text { Square }\end{array}$} & \multirow{3}{*}{$\begin{array}{l}\text { Regulari } \\
\text { zation "R } \\
\text { Square" } \\
\text { (1-Error) }\end{array}$} & \multirow{3}{*}{$\begin{array}{l}\text { Apparent } \\
\text { Prediction } \\
\text { Error }\end{array}$} & \multicolumn{2}{|c|}{ Expected Prediction Error } \\
\hline & & & & & & \\
\hline & & & & & Estimate $^{\mathrm{a}}$ & Std. Error \\
\hline 0.7611 & 0.7415 & 0.6346 & 9.4671 & 0.0010 & 0.0020 & 0.000 \\
\hline
\end{tabular}

Sumber : Data Primer Setelah diolah, 2018

$$
Y=93,54-3,02 X_{1}-7,00 X_{2}+7,40 X_{3}+1,43 X_{4}+9,78 X_{5}+3,38 X_{6}+3,17 X_{7}
$$

Hasil Analisa Uji Lanjutan Pengaruh Karaktersitik Responden Terhadap Pola Pangan Harapan

\begin{tabular}{llll}
\hline \hline Variabel Bebas & Koefisien Regresi & T- Hitung & Sig \\
\hline \hline Umur & $-3,02$ & $-0.86^{* *}$ & -0.02 \\
Jumlah Tanggungan & $-7,00$ & $-0.47^{*}$ & -0.13 \\
Pendidikan & 7,40 & $2.48^{*}$ & 1.76 \\
Pekerjaan & 1,43 & $0.43^{\text {tn }}$ & 0.65 \\
Pengalaman & 9,78 & $0.72^{\text {tn }}$ & 0.81 \\
Pendapatan & 3,38 & $1.86^{* *}$ & 0.05 \\
Pengeluaran & 3,17 & $1.77^{* *}$ & 0.12 \\
\hline \hline
\end{tabular}

Sumber : Data primer yang telah diolah, 2018

Keterangan :

$$
\begin{array}{ll}
* & =\text { nyata pada tingkat keprcayaan } 95 \% \\
* * & =\text { sangat nyata pada tingkat kepercayaan } 95 \% \\
\text { tn } & =\text { tidak nyata pada tingkat kepercayaan } 95 \%
\end{array}
$$

\section{Kesimpulan}

1. Karaktersitik demografi, sosial dan ekonomi masyarakat sekitar kawasan hutan berada pada kisaran umur produktif (40 - 50 tahun) sebesar $60,00 \%$, jumlah tanggungan keluarga banyak $(3-$ 4 orang) sebesar $65,00 \%$, tingkat pendidikan rendah (SD/Sederajat) sebesar 55,0\%, jenis pekerjaan sampingan umumnya adalah pekebun $(62,50 \%)$, pengalaman berusahatani terlama pada kisaran 20 - 30 tahun $(60,00 \%)$, pendapatan rata-rata terbesar adalah Rp. 2.000.000Rp.3.000.000/Bulan (52,50\%), dan pengeluaran rata-rata terbanyak adalah Rp. 1.500.000 - Rp. 3.000.000 $(90,0 \%)$ 
2. Pola konsumsi pangan masyarakat sekitar kawasan hutan sesuai dengan skor nilai Pola Pangan Harapan (PPH) adalah 97,8 yang berarti bahwa distribusi dan ketersediaan pangan bagi rumah tangga terjamin dengan komposisi dan ketersediaan bahan-bahan pangannya tercukupi.

3. Karakteristik demografi, sosial dan ekonomi yang berpengaruh signifikan terhadap Pola Pangan Harapan (PPH) masyarakat sekitar kawasan hutan adalah umur, jumlah tanggungan keluarga, pendidikan, pendapatan dan pengeluaran

\section{Saran}

Untuk meningkatan kualitas dan kuantitas pola pangan masyarakat sekitar kawasan hutan melalui pembangunan hutan rakyat, perlu ditingkatkan kondisi sosial ekonomi petaninya, terutama pendidikan. Pemerintah Daerah Kabupaten Takalar disarankan bisa mempercepat perbaikan kondisi sosial ekonomi petani dengan memprioritaskan revitalisasi sarana dan prasarana produksi di Kabupaten Takalar meliputi hal-hal: perbaikan jalan, akses terhadap informasi usahatani dan sumber permodalan, penyediaan dan perluasan pasar, dan penguatan kelembagaan.

\section{DAFTAR PUSTAKA}

Ariani M. 1993. Kajian pola konsumsi pangan dan permintaan pangan serta proyeksi kebutuhan pangan pada repelita VI di tiga provinsi di indonesia (tesi). Bogor. Program pasca sarjana, Institusi pertanian Bogor.

Antang. 2012. Ketahanan Pangan dan Kebiasaan Makan Rumah Tangga pada Masyarakat yang Tinggal di Daerah Sekitar Lahan Gambut Kalimantan Tengah. Tesis Magister. IPB, Bogor.

Aspatria U. 1996. Studipola konsumsi pangan masyarakat dengan pendekatan karaketristik agroekologi di Kabupaten Kupang (tesis). Bogor. Program pasca sarjana, Institusi pertanian Bogor.

Badan Litbang Kehutanan dan Perkebunan. 2015. Pedoman survei sosial ekonomi kehutanan Indonesia. Pusat Penelitian Sosial Ekonomi Kehutanan dan Perkebunan. Badan Litbang Kehutanan dan Perkebunan. Departemen Kehutanan dan Perkebunan.

(BPS) Badan Pusat Statistik. 2015a. Pengeluaran untuk konsumsi penduduk Indonesia 2015. Jakarta:BPS. 